\section{(อ) OPEN ACCESS}

\title{
Simultaneous bilateral aqueous misdirection following certolizumab therapy for rheumatoid arthritis
}

\author{
Leif Hynnekleiv, ${ }^{1}$ Alexander Stanley Thrane, ${ }^{1}$ Jørgen Krohn ${ }^{1,2}$
}

'Department of Ophthalmology, Haukeland University Hospital, Bergen, Norway ${ }^{2}$ Department of Clinical Medicine, Section of Ophthalmology, University of Bergen, Bergen, Norway

Correspondence to Dr Leif Hynnekleiv; leif.hynnekleiv@gmail.com

Accepted 13 September 2020

Check for updates

(c) BMJ Publishing Group Limited 2020. Re-use permitted under CC BY-NC. No commercial re-use. See rights and permissions. Published by BMJ.

To cite: Hynnekleiv $\mathrm{L}$, Thrane AS, Krohn J. BMJ Case Rep 2020;13:e235194. doi:10.1136/bcr-2020235194

\section{SUMMARY}

Aqueous misdirection syndrome is a rare, incompletely understood, sight-threatening eye condition that is difficult to diagnose and treat. We present a case of simultaneous bilateral aqueous misdirection following the administration of certolizumab in a 41-year-old women with rheumatoid arthritis and no known risk factors. To our knowledge, aqueous misdirection has not previously been associated with the use of tumour necrosis factor-alpha inhibitors.

\section{BACKGROUND}

Aqueous misdirection syndrome (AMS), also known as malignant glaucoma, is a sight-threatening condition associated with a uniform shallowing of the anterior chamber and normal or elevated intraocular pressure (IOP). ${ }^{1}$ The exact mechanism is incompletely understood, but thought to be related to a redirection of aqueous humour into the vitreous due to anterior rotation of the ciliary body with consequent ciliolenticular and/or vitreous block. AMS can occur spontaneously, but is most frequently seen in the context of cataract or glaucoma surgery. ${ }^{1}$ Other risk factors include hyperopia and previous angle-closure. The diagnosis is made by the observation of axial flattening of the anterior chamber despite a patent iridotomy, in the presence of elevated or sometimes normal IOP. Miotics can worsen AMS, while cycloplegics may improve the condition. Most patients require neodymiumdoped yttrium aluminum garnet (Nd:YAG) laser anterior hyaloidotomy with posterior capsulotomy if pseudophakic or phacoemulsification combined with pars plana vitrectomy if phakic. ${ }^{1}$ Certolizumab pegol is a pegylated antigen-binding fragment $(\mathrm{Fab})$ of humanised tumour necrosis factor-alpha (TNFa) antibody, ${ }^{2}$ used for the treatment of rheumatoid arthritis, ankylosing spondylitis, Crohn's disease and other autoimmune diseases. ${ }^{3}$ Herein, we report an unusual case of simultaneous bilateral AMS associated with certolizumab therapy for rheumatoid arthritis.

\section{CASE PRESENTATION}

A 41-year-old women, with rheumatoid arthritis and no history of eye disease or surgery, was admitted to the neurology department with acute blurred vision and headache of 3-4 weeks duration. A transient ischaemic attack was first suspected, but neurological workup and imaging were normal. During the past 4 years, she had been treated with prednisolone and various disease-modifying antirheumatic drugs (sulfasalazine, infliximab, etanercept, adalimumab) without satisfactory response. Five weeks prior to presentation, she had started on $400 \mathrm{mg}$ certolizumab pegol injections every 2 weeks. Apart from oral prednisolone, $15 \mathrm{mg} /$ day, she had not been using any other drugs during the last month before starting certolizumab. An erythematous rash developed at the injection site 9 days after the first certolizumab injection. After the second injection, 2 weeks later, she was therefore given a single dose of oral cetirizine $10 \mathrm{mg}$. The third and last certolizumab injection was 6 days prior to presentation, given at half dose $(200 \mathrm{mg})$ together with cetirizine $10 \mathrm{mg} /$ day for 3 days to reduce the symptoms and appearance of the local skin reaction. Her uncorrected visual acuity (VA) was 20/200 in both eyes (OU). Despite a history of emmetropia, a best-corrected VA of 20/30 OU was achieved with a spherical equivalent correction (SEC) of -6 and -6.25 dioptres (D) in the right eye (OD) and left eye (OS), respectively. Slit-lamp examination revealed a uniform shallowing of the anterior chambers, with anterior displacement of the lens-iris complex and no signs of choroidal effusion (figure 1). Gonioscopy showed almost completely occluded angles, and IOP was $36 \mathrm{~mm}$ $\mathrm{Hg}$ bilaterally. Acute angle-closure glaucoma was suspected, and she was given maximal IOPlowering medication and bilateral $\mathrm{Nd}$ :YAG laser iridotomy aided by pilocarpine $2 \%$. The following morning, IOP was $14 \mathrm{~mm} \mathrm{Hg}$ OU, but the anterior chambers were still very shallow, and her refractive error had increased to -7.25 and $-8.00 \mathrm{D}$. Optical biometry revealed shallow anterior chamber depths of $1.16 \mathrm{~mm}$ and $1.43 \mathrm{~mm}$, normal lens thicknesses of $4.39 \mathrm{~mm}$ and $4.43 \mathrm{~mm}$ and normal axial lengths of 23.57 and $23.47 \mathrm{~mm}$ in OD and OS, respectively. B-scan ultrasonography was performed to exclude choroidal effusion. Based on the clinical course and ancillary findings, a diagnosis of bilateral AMS was made. Bilateral Nd:YAG laser anterior hyaloidotomy was performed followed by topical cyclopentolate $0.5 \%$, dexamethasone $0.1 \%$, dorzolamide/timolol and oral prednisolone. Immediately after the hyaloidotomy, a significant deepening of the anterior chambers was observed. Four hours later, normal anterior chamber depths were 


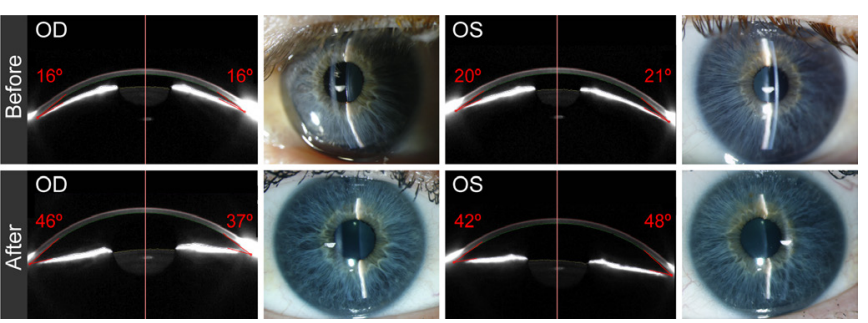

Figure 1 Scheimpflug images and slit-lamp photographs of the anterior segment. Clinical images demonstrating the anterior displacement of the lens-iris diaphragm and narrow chamber angle in both eyes prior to laser anterior hyaloidotomy (top row). One day after treatment, there is a marked deepening of the anterior chambers (bottom row). The Scheimpflug images were acquired using Pentacam (Oculus, Lynnwood, Washington, USA), and the numbers in red indicate the automatically calculated anterior chamber angle width. OD: right eye. OS: left eye.

noted, and the IOP was $13 \mathrm{~mm} \mathrm{Hg}$ and $12 \mathrm{~mm} \mathrm{Hg}$ in OD and OS, respectively (figure 1).

\section{OUTCOME AND FOLLOW-UP}

After 4 days, her VA was 20/20 OU with a SEC of +0.2 D OD and +0.0 D OS. Certolizumab was discontinued due to the high probability of being the causative agent. Within 4 weeks, all topical medications were withdrawn, and the IOP remained within the normal range. Four months follow-up revealed normal visual fields, normal IOP, normal peripapillary retinal nerve fibre layers by spectral domain optical coherence tomography, stable emmetropia and normal visual function without any other complaints. Her rheumatoid arthritis was subsequently treated with oral prednisolone $5-20 \mathrm{mg} /$ day, adjusted according to clinical response.

\section{DISCUSSION}

Spontaneous bilateral AMS is a rare event, ${ }^{4}$ and only six cases are reported in the literature. ${ }^{5-10}$ A limitation of our study is the lack of ultrasound biomicroscopy (UBM) due to equipment malfunction. UBM may have helped to identify the status of the ciliary body and processes as well as possible ciliary body effusion that can precipitate AMS. ${ }^{1}$ Pupillary block glaucoma has been associated with certain antihistamines owing to their weak anticholinergic activity. ${ }^{11}$ Cetirizine, however, has a negligible anticholinergic activity, and we have not found any reports in the literature on an association between cetirizine medication and pupillary block or angle-closure. In our patient, there is substantial evidence against a pupillary block, and for an AMS mechanism, including a lack of resolution after iridotomy, a uniform shallowing of the anterior chambers and an increasing myopic shift following miotics. A possible molecular explanation for the association between certolizumab and AMS could be an inhibition of TNF- $\alpha$-induced expression of the vasoactive and smooth muscle-contracting peptide endothelin- 1 in the ciliary body, ${ }^{12} 13$ which may have altered the normal dynamics of aqueous humour and thereby led to its misdirection. To the best of our knowledge, this is the first report of AMS following the administration of a TNF- $\alpha$ inhibitor. Although our report is based on a single case and other causes cannot be completely ruled out, the time course and the lack of any predisposing risk factors suggest that the bilateral AMS in our patient was induced by certolizumab. Patients with known risk factors such as axial hyperopia and a history of primary angle-closure may need to be followed more closely with UBM after starting certolizumab.

\section{Learning points}

- Aqueous misdirection syndrome (AMS) is a diagnostic and therapeutic challenge, where immediate recognition and treatment can improve the outcome.

- AMS may first present to non-ophthalmologists and masquerade as an acute neurological condition.

- An insidious increase in intraocular pressure, a shallow anterior chamber both centrally and peripherally, and an increasing myopic shift are signs to look out for.

- Bilateral AMS rarely occurs spontaneously in patients without any risk factors.

- Cycloplegics and laser anterior hyaloidotomy may reverse the condition.

Contributors AST and LH were responsible for managing the patient. All authors contributed to writing the manuscript and approved the final version.

Funding The authors have not declared a specific grant for this research from any funding agency in the public, commercial or not-for-profit sectors.

Competing interests None declared.

Patient consent for publication Obtained.

Provenance and peer review Not commissioned; externally peer reviewed.

Open access This is an open access article distributed in accordance with the Creative Commons Attribution Non Commercial (CC BY-NC 4.0) license, which permits others to distribute, remix, adapt, build upon this work non-commercially, and license their derivative works on different terms, provided the original work is properly cited and the use is non-commercial. See: http://creativecommons.org/ licenses/by-nc/4.0/.

\section{REFERENCES}

1 Kaplowitz K, Yung E, Flynn R, et al. Current concepts in the treatment of vitreous block, also known as aqueous misdirection. Surv Ophthalmol 2015;60:229-41.

2 Graudal N, Kaas-Hansen BS, Guski L, et al. Different original and Biosimilar TNF inhibitors similarly reduce joint destruction in rheumatoid arthritis-a network metaanalysis of 36 randomized controlled trials. Int J Mo/ Sci 2019;20:pii: E4350.

3 Deeks ED. Certolizumab pegol: a review in inflammatory autoimmune diseases. BioDrugs 2016;30:607-17.

4 González-Martín-Moro J, Iglesias-Ussel L, Cobo-Soriano R, et al. Spontaneous malignant glaucoma: case report and review of the literature. Saudi J Ophthalmol 2019;33:398-400

5 Manku MS. Spontaneous bilateral malignant glaucoma. Aust N Z J Ophthalmol 1985; 13:249-50

6 Gonzalez F, Sanchez-Salorio M, Pacheco P. Simultaneous bilateral "malignant glaucoma" attack in a patient with no antecedent eye surgery or miotics. Eur $J$ Ophthalmol 1992:2:91-3.

7 Amini H, Fekrat N, Razeghinejad MR. Simultaneous spontaneous bilateral malignant glaucoma attack in a young patient with bilateral posterior polar cataract. Ann Ophthalmol 2005:37:285-8

8 Jarade EF, Dirani A, Jabbour E, et al. Spontaneous simultaneous bilateral malignant glaucoma of a patient with no antecedent history of medical or surgical eye diseases. Clin Ophthalmol 2014;8:1047-50.

9 Adekoya BJ, Balogun MM, Balogun BG, et al. Malignant glaucoma: report of a presumed bilateral spontaneous case. East and Central African Journal of Surgery 2014;19:55-9.

10 Feng L, Roufas A, Healey PR, et al. Bilateral spontaneous aqueous misdirection: it can happen! Clin Exp Ophthalmol 2015;43:771-3.

11 Razeghinejad MR, Myers JS, Katz LJ. latrogenic glaucoma secondary to medications. Am J Med 2011;124:20-5.

12 Prasanna G, Dibas A, Tao W, et al. Regulation of endothelin-1 in human nonpigmented ciliary epithelial cells by tumor necrosis factor-alpha. Exp Eye Res 1998:66:9-18.

13 Prasanna G, Dibas Al, Yorio T. Cholinergic and adrenergic modulation of the $\mathrm{Ca} 2+$ response to endothelin-1 in human ciliary muscle cells. Invest Ophthalmol Vis Sci 2000;41:1142-8. 
Copyright 2020 BMJ Publishing Group. All rights reserved. For permission to reuse any of this content visit https://www.bmj.com/company/products-services/rights-and-licensing/permissions/

BMJ Case Report Fellows may re-use this article for personal use and teaching without any further permission.

Become a Fellow of BMJ Case Reports today and you can:

- Submit as many cases as you like

- Enjoy fast sympathetic peer review and rapid publication of accepted articles

- Access all the published articles

Re-use any of the published material for personal use and teaching without further permission

Customer Service

If you have any further queries about your subscription, please contact our customer services team on +44 (0) 2071111105 or via email at support@bmj.com.

Visit casereports.bmj.com for more articles like this and to become a Fellow 